\title{
Building Smart Communication in Service Library
}

\section{Membangun Kecerdasan Komunikasi dalam Layanan di Perpustakaan}

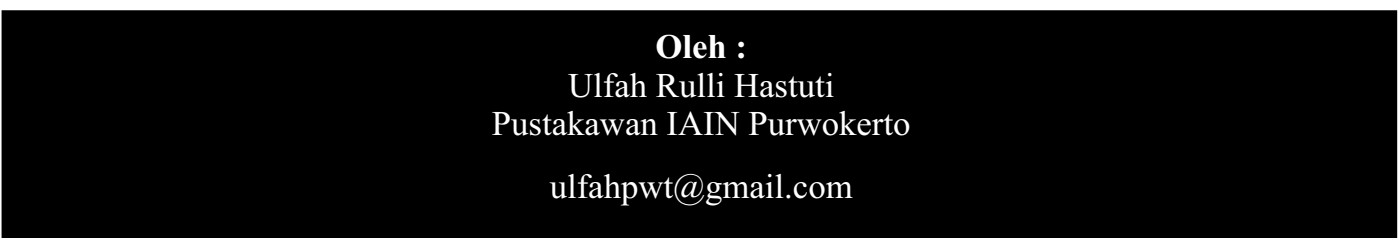

Abstrak. Salah satu upaya perpustakaan dalam memenuhi harapan pemustaka adalah meningkatkan layanan kepada pemustaka. Komunikasi dalam konteks layanan perpustakaan mengajarkan kepada kita bagaimana berkomunikasi, berinteraksi, menjalin hubungan dengan pemustaka atau pemakai perpustakaan sehingga tercipta kesan yang menarik dan dapat memberikan kepuasan kepada pengguna atau penerima layanan. Pemberian layanan jasa berupa informasi kepada pemakai identik dengan sikap melayani. Komunikasi yang cerdas merupakan strategi komunikasi yang tepat untuk diterapkan dalam layanan di perpustakaan. Dengan membangun kecerdasan komunikasi dalam layanan di perpustakaan sangat diharapkan pemustaka akan merasa puas dalam memenuhi kebutuhan informasi dan merasa nyaman berada di perpustakaan. Kecerdasan komunikasi untuk layanan diperpustakaan dibangun dengan menerapkan prinsip-prinsip komunikasi yaitu berbicara yang benar dalam memberikan bantuan informasi, menggunakan kata-kata yang efektif dalam merespon pesan atau kebutuhan pemustaka, menggunakan kata-kata yang pantas untuk menghargai pemustaka dan bertutur kata lemah lembut dalam memberikan bimbingan. Dengan menerapkan kelima prinsip komunikasi dalam layanan di perpustakaan selain dapat mewujudkan layanan prima juga akan memberikan citra yang baik bagi perpustakaan.

\section{Kata kunci : layanan perpustakaan, kecerdasan komunikasi, layanan prima}

Abstract. One the performances library in full fill expectation of user is increasing services for user. Communication in the context of library services is to teach us how we make communication, interaction in connection whith user to make good impression of interesting so give satisfaction to user. Giving of service of information for user is identical with an attitude of service. Smart communication is communication strategy in library service. Building smart communication in library service is hope user be satisfaction in searching information and comfortable in library. Smart communication in the library service use principals of communication which are giving valid information, using effective word in respond and interaction, warm and friend in the gesture of body language. By practice these principals, it will implemented a good services and a good performance for library.

Keyword : library service, smart communication, excellent service 


\section{PENDAHULUAN}

Beberapa potensi kecerdasan yang dimiliki manusia diantaranya yaitu kecerdasan intelektual, kecerdasan emosional dan kecerdasan spiritual. Ketiga potensi kecerdasan yang dimiliki manusia ini mendorong para ilmuwan untuk mengadakan penelitian dan menemukan berbagai keunikan. Dalam penelitiannya Goleman menyimpulkan bahwa kecerdasan intelektual hanya memberikan kontribusi $20 \%$ terhadap kesuksesan seseorang sedangkan $80 \%$ dipengaruhi oleh kecerdasan lain. Kecerdasan emosi ini sangat besar pengaruhnya dalam dunia kerja karena sarat dengan motivasi, kesadaran diri, empati, simpati dan solidaritas yang tinggi.

Dalam konteks perpustakaan layanan adalah kegiatan pokok yang harus diutamakan sehingga dalam memberikan layanan, pustakawan dituntut untuk mempunyai kemampuan komunikasi yang cerdas. Ketersediaan koleksi dan sumber referensi yang lengkap, sarana prasarana yang modern di perpustakaan sebagai pendukung pembelajaran bagi pemustaka tidak dapat optimal pemanfaatannya jika layanan yang diberikan sangat buruk. Pelayanan yang buruk membawa dampak ketidakpuasan bagi pemustaka. Ketidakpuasan yang dikeluhkan menjadi informasi penting bagi sebuah organisasi yang bergerak di bidang jasa seperti perpustakaan sehingga perlu adanya strategi perbaikan manajemen layanan.

Keluhan dari pemustaka atas layanan yang kurang memuaskan dalam proses layanan di perpustakaan masih sering terdengar, meski mereka mengungkapkan secara tidak langsung. Koleksi yang kurang lengkap, suasana perpustakaan yang kurang nyaman baik dalam kebersihan maupun keamanan, keramahan petugas dalam menjalankan layanan adalah hal yang dikeluhkan pemustaka. Segala permasalahan yang terkait dengan pemustaka khususnya ketidakpuasan dengan sikap petugas dalam menjalankan layanan, diperlukan upaya untuk perbaikan khususnya aspek sumber daya manusianya yaitu petugas layanan. Membekali pustakawan beserta seluruh staf yang bertugas dengan kecerdasan komunikasi merupakan problem solving yang dapat ditempuh oleh pimpinan perpustakaan. Hal inilah yang mendorong penulis untuk melakukan studi pustaka tentang kecerdasan komunikasi dalam layanan di perpustakaan. Dari identifikasi tersebut maka rumusan masalah dalam studi pustaka ini adalah :Bagaimana membangun kecerdasan komunikasi untuk layanan jasa di perpustakaan? Tujuan dari studi pustaka ini adalah untuk mengetahui kecerdasan komunikasi yang baik seperti apa untuk diterapkan oleh pustakawan dalam memberikan layanan diperpustakaan sehingga layanan prima 
dapat diwujudkan. Dengan adanya studi pustaka ini diharapkan akan bermanfaat untuk mewujudkan layanan prima bagi pemustaka sehingga pemustaka merasa puas dengan memanfaatkan produk yang ada di perpustakaan dan pada akhirnya akan meningkatkan citra perpustakaan melalui layanan yang diberikan.

\section{PEMBAHASAN}

Dalam penelitian ini penulis menggunakan metode pengumpulan data kualitatif dengan menganalisis dokumen tentang topic yang dibahas. Kecerdasan merupakan suatu anugerah kemampuan dari tuhan yang harus kita syukuri. Defini kecerdasan menurut Piaget seperti yang dikutip oleh Agus Efendi (2005 : 83) Intelligence is what you use when you don't know what to do (kecerdasan adalah apa yang kita gunakan pada saat kita tidak tahu apa yang harus dilakukan. Dalam dunia kerja terutama yang berhubungan dengan pelanggan sangat diperlukan kemampuan untuk memahami perasaan, temperamen, suasana hati, maksud dan keinginan orang lain dan menanggapinya secara cerdas. Menurut May Lawin (2008 : 197) kemampuan ini termasuk dalam kecerdasan interpersonal. Orang-orang yang mempunyai kecerdasan interpersonal sangat mudah bergaul dan menjalin hubungan persahabatan dan mereka mempunyai kemampuan mempertimbangkan perasaan orang lain dan tahu bagaimana membuat orang lain merasa dihargai. Kecerdasan inilah yang paling penting dalam berkomunikasi karena dalam komunikasi yang sehat diperlukan kepribadian yang hangat dalam istilah jawa kepribadian yang supel. Menurut Stenberg dalam kutipan Agus Efendi (2005 : 86) kecerdasan mencakup bagaimana kita menangani sebuah pekerjaan, bagaimana berhubungan dengan orang lain, dan bagaimana mengelola kehidupan kita secara umum

Komunikasi adalah suatu proses sosial yang terjadi antara sediktnya dua orang, dimana individu mengirim stimulus kepada orang lain. Stimulus dapat diartikan sebagai pesan verbal yang disampaikan kepada komunikan sehingga mendapat respon pada pesan yang disampaikan. Rismi Somad \& Donni Juni Priansa (2014 : 115). Bagaimana supaya komunikator sebagai pihak yang menyampaikan pesan mendapat respon yang baik seperti yang diharapkan? Pesan yang disampaikan melalui komunikas diharapkan dapat diterima dan dipahami oleh penerima. Proses penyampaian pesan dalam komunikasi akan efektif dengan menggunakan strategi yang tepat. Beberapa prinsip komunikasi efektif yang harus diperhatikan agar pesan yang disampaikan mendapat respon sesuai dengan yang diharapkan menurut Rismi Somad \& Juni P. (2014 : 151) adalah (1) menghargai; (2) empati; (3) memahami; (4) jelas ; (5) rendah hati. Komunikasi 
yang terjadi dalam organisasi perpustakaan tergolong dalam komunikasi resmi atau formal. Pelayanan di perpustakaan baik yang menerapkan system layanan terbuka atau system layanan tertutup pada dasarnya melayani pemustaka dengan beberapa metode yaitu metode kontak langsung dengan pemustaka, melalui saluran telepon, dan komunikasi tertulis. Selain prinsip dan penggunaan metode yang diterapkan dalam komunikasi antara pemustaka sebagai pelanggan informasi dan pustakawan di perpustakaan, ada elemen penting yang harus memperhatikan agar komunikasi menjadi efektif dan layanan prima dapat terwujud yaitu kata-kata, suara, dan bahasa tubuh.

\section{Layanan Dalam Perpustakaan}

Dalam organisasi Perpustakaan berperan sebagai penyedia layanan ( service provider) adalah pihak yang memberikan layanan jasa (services) yang bukan mencari laba (non-profite motive). Dalam Kamus Besar Bahasa Indonesia ( KUBI, 2007 : 646) Hakikat layanan berarti perihal atau cara melayani. Dalam bidang informasi berarti pelayanan informasi yang diberikan suatu kantor atau perusahaan melalui telephone, atau surat sebagai jawaban atas berbagai hal yang ditayangkan mengenai informasi. Layanan perpustakaan adalah suatu kegiatan pemerian layanan jasa kepada pengguna atau pemakai (user). Pemberian layanan jasa berupa informasi kepada pemakai berkaitan dengan penyediaan segala bentuk bahan perpustakaan yang dibutuhkan dan menyediakan berbagai sarana penelusuran informasi yang dibutuhkan pemakai. Berkaitan dengan layanan perpustakaan Sutarno NS (2006 : 193) berpendapat bahwa layanan di perpustakaan membutuhkan kemampuan, keterampilan, dan pengalaman serta "penguasaan" sumber informasi di perpustakaan.

Sebagai salah satu pusat informasi perpustakaan disebut juga sebagai pelaku usaha nirlaba yang bergerak dalam bidang pelayanan informasi. Sebagai penerima layanan (service receiver) dari kegiatan perpustakaan disebut sebagai pelanggan. Menurut Atep Arya Barata (2004 : 13) pelanggan dibedakan menjadi dua yaitu : Pelanggan internal dan pelanggan eksternal. Demikian juga dalam dunia perpustakaan terdiri dari pelanggan internal dan pelanggan eksternal. Pelanggan internal atau konsumen internal adalah orang-orang yang terlibat dalam proses penyediaan jasa.

Pemakai perpustakaan baik itu kalangan mahasiswa, dosen, karyawan atau masyarakat umum membutuhkan penghargaan dan pengakuan sebagai pelanggan (customer) saat berkunjung ke perpustakaan. Penghargaan yang dimaksud adalah adanya sikap terbuka dan keramahan petugas dalam memberikan layanan. Bagaimana 
perpustakaan sebagai lembaga non-profit yang bergerak dalam bidang informasi mampu memenuhi harapan pemakai sebagai pelanggannya? Dengan menyediakan sumber referensi yang lengkap dan terkini (uptodate), melengkapi sarana prasarana dengan teknologi informasi dan satu hal yang tidak kalah penting adalah memberikan layanan prima kepada pemustaka.

\section{Komunikasi Dalam Layanan} Perpustakaan

Dalam rangka meningkatkan layanan kepada pelanggan atau pengguna, kemampuan komunikasi menjadi hal penting dalam organisasi yang bergerak dalam bisnis layanan jasa. Seperti halnya perpustakaan yang merupakan lembaga nirlaba dibidang layanan jasa informasi, kemampuan dan keterampilan komunikasi sangat penting untuk mendukung kegiatan layanan . Kecerdasan komunikasi merupakan kemampuan dalam menyampaikan pesan yang disertai dengan motivasi dan kesadaran diri untuk memberikan suatu layanan pada pelanggan. Kecerdasan komunikasi dalam layanan perpustakaan dapat diaplikasikan dengan menerapkan beberapa prinsip komunikasi seperti yang diungkapkan oleh Ellys Lestari Pembayun (2012 : 41) dalam kegiatan pelayanan agar dapat mencapai layanan yang optimal. Prinsip berikut ini menurut penulis sangat tepat jika diimplementasikan dalam kegiatan layanan di perpustakaan. Prinsip komuikasi yang bersifatdasar namun sarat dengan mak mudah untuk dilakukan karena pada dasarnya prinsip ini sudah biasa dipakai dalam komunikasi dalam kehidupan sehari-hari baik di rumah, kantor atau di tempat-tempat umum. Prinsip-prinsip menurut Ellys untuk membangun kecerdasan komunikasi adalah

\section{Pertama Prinsip Qawlan Sadidan ( Berbicara Benar)}

Yaitu berbicara dengan benar, jujur, lurus ( to the point), dan tidak bohong, dan tidak berbelit-belit. Dalam dunia perpustakaan sebagai penghasil informasi yang tidak pernah lepas dari komunikasi prinsip pertama ini sangat penting dan harus diterapkan dalam setiap titik layanan. Sebagai penyedia informasi hendaknya kita harus senanatiasa berusaha memberikan dan menyampaikan informasi yang benar, tidak manipulasi dan tidak berbelit-belit kepada pengguna yang datang dan mencari informasi. Artinya ketika ada pengguna atau pemustaka meminta bantuan informasi mengenai suatu subjek kita harus mengatakan yang sebenarnya dan tidak terkesan mengada-ada sehingga pengguna tidak merasa dibohongi. Prinsip ini harus dimiliki oleh setiap individu dimana pun kita bekerja . 
Kedua Prinsip Qawlan Balighan (katakata Efektif)

Merupakan prinsip komunikasi yang efektif. Artinya dalam kegiatan layanan jasa di perpustakaan tentu saja melibatkan pelanggan kita harus berusaha untuk mengerti apa yang dibutuhkan pengguna ketka datang ke perpustakaan, apa yang dikeluhkan (apa yang dirasakan) pengguna kaitannya dengan jasa yang kita sediakan. Sebagai manajer informasi di perpustakaan kita dituntut untuk mempunyai kemampuan untuk memahami pembicaraan atau pesan dari pengguna dan menafsirkan dengan tepat apa yang dibutuhkan oleh pengguna sehingga dengan kita memahami apa yang dibutuhkan oleh pengguna kita dapat memberikan respon atau jawaban yang tepat sehingga akan tercipta kesepahaman dan pada akhirnya tercapai tujuan layanan yang optimal. Sebagai manajer informasi hendaknya kita dapat menghindari sikap menghakimi, atau menyangggah pernyataan dari pengguna perpustakaan.

\section{Ketiga Prinsip Qawlan Maysuran (Kata-kata yang Pantas )}

Ucapan ibarat mata pisau yang dapat mematahkan apa-pun dan melukai diri jika kita tidak berhati-hati dalam pemakaiannya. Begitu kiasan bahaya dari sebuah ucapan atau kata-kata dari lisan yang kehilangan kesantunannya. Dengan menerapkan komunikasi yang santun dalam pelayanan perpustakaan maka akan mendatangkan nilai positif dalam proses interaksi antar pegawai dengan pengguna perpustakaan.

Profesi pustakawan berada di perpustakaan adalah sebagai pelayan masyarakat yang harus melayani semua pemustaka tanpa membedakan apa pun latar latar belakang pendidikan, suku dan agamanya. Dalam melayani pengguna perpustakaan seharusnya kita dapat membingkai sikap, perilaku dan komunikasi dengan nilai-nilai agama dan moral.

Qawlan Maysuran dalam konteks pelayanan perpustakaan sangat besar pengaruhnya. Maka dari itu ucapkanlah kata-kata yang pantas, luwes, indah dan terasa nyaman didengar serta tidak menyinggung atau merendahkan pengguna perpustakaan. Dalam komunikasi pelayanan muwafik berpendapat ada beberapa pilihan kata yang hendaknya kita hindari dalam pelayanan yaitu

\section{Keempat Prinsip Qawlan Layinan lemah lembut )}

Artinya kemampuan berinteraksi berbicara dengan baik dan halus sehingga dapat memberikan pengaruh yang kuat dengan orang yang diajak berbicara. Dalam konteks pelayanan perpustakaan setiap interaksi dengan pengguna perpustakaan wajib bagi kita sebagai manajer informasi memberi kenyamanan pada mereka dengan bertutur kata yang 
lembut dalam semua unit layanan.

Dalam memberikan bimbingan pada pengguna hendaknya disampaikan dengan lemah lembut terutama bagi pengguna yang tergolong anggota baru yang masih asing dengan perpustakaan. Sikap dan tutur kata yang baik (lembut dan tegas) merupakan langkah awal yang baik dalam berkomunikasi. Kesan yang tercipta memberikan penilaian yang positif bagi kita sebagai penyedia informasi ( information provider), sehingga pengguna akan yakin bahwa kita adalah sumber informasi yang dapat membantu dan sangat dibutuhkan. Berilah pemahaman dengan lemah lembut tentang apa ditanyakan dan hal-hal yang perlu diketahui oleh pengguna.

\section{Kelima Prinsip Qawlan Kariman (perkataan yang mulia)}

Pada dasaranya manusia diciptakan tuhan dibekali berbagai potensi dan sifat mulia agar kelak dapat menjadi hamba yang dapat mengemban amanah yang mulia. Perbedaan warna kulit,ras, golongan ,tinggi badan,jenis rambut hanyalah perbedaan fisik.. Dalam komunikasi salah satu kata yang terkandung dalam kecerdasan komunikasi adalah kata maaf. Dalam konteks pelayanan perpustakaan ungkapan maaf lazim diungkapkan untuk mengingatkan pengguna ( (user) dalam hal ini mahasiswa, dosen, pegawai yang tidak mentaati peraturan misalnya masuk ruang koleksi membawa tas atau merokok di ruang baca."mohon maaf silahkan tasnya disimpan diloker." Ungkapan lain dalam kecerdasan komunikasi yang lazim kita dengar di perpustakaan adalah ucapan terima kasih. Sebagai pusat informasi yang bergerak dalam bidang pemasaran jasa ungkapan terima kasih sangat familiar kita dengar dari pengguna yang telah memakai jasa layanan perpustakaan. Tidak terhitung lagi jumlah ungkapan terima kasih yang kita terima dari pengguna yang datang ke perpustakaan.

Dengan menerapkan kelima prinsip seperti yang di paparkan di atas ke dalam layanan di perpustakaan menurut penulis sangat besar manfaatnya. Hal ini karena dalam pelayanan khususnya di perpustakaan, selain harus memperhatikan elemen penting komuniksi kelima prinsip yang bersumber dari hati nurani dan dilakukan dengan kesadaran akan tanggungjawab sebagai penyedia informasi untuk menyebar luaskan ilmu pengetahuan sangat tepat untuk mendukung terwujudnya layanan prima bagi pemustaka.

\section{SIMPULAN}

Kecerdasan komunikasi dalam konteks layanan perpustakaan adalah hal pokok yang harus diutamakan, oleh karena itu pustakawan dan segenap pegawai yang bertugas di bagian layanan perpustakaan harus membekali diri 
dengan kecerdasan dan keterampilan komunikasi. Dengan membangun komunikasi yang cerdas merupakan usaha agar penyampaian pesan dan informasi dapat mencapai tujuan dan sekaligus menjadi sarana untuk mempromosikan produk yang dimiliki. Mengutamakan layanan yang berkualitas adalah sebuah komitmen yang harus dibangun bersama melalui komunikasi yang cerdas antara pustakawan dan pemustaka. Produk yang unggul dan sarana yang lengkap akan lebih sempurna jika dilengkapi dengan pemberian layanan prima. Dengan menerapkan kecerdasan komunikasi dalam layanan di perpustakaan diharapkan pemustaka akan merasa puas dalam memenuhi kebutuhan keilmuannya Dengan demikian layanan perpustakaan mencapai hasil yang optimal dan hal ini menjadi salah satu strategi dalam pemasaran perpustakaan. Pada akhirnya kecerdasan komunikasi dapat dibangun dengan menerapkan prinsip-prinsip komunikasi yang telah dipaparkan dalam pembahasan di atas dengan harapan akan dapat mewujudkan layanan prima bagi pemustaka dan akan meningkatkan citra yang baik bagi perpustakaan.

\section{DAFTAR PUSTAKA}

Barata,Atep Adya. (2004). Dasar-dasar Pelayanan Prima. Jakarta : Elex Media Komputindo.

Efendi,Agus. (2005 ). Revolusi
Kecerdasan Abad 21 : kritik MI, EI, SQ, AQ \& Successful Inteligence atas IQ. Alfabeta. Bandung

Kamus Besar Bahasa Indonesia. (2007).Jakarta: Balai Pustaka

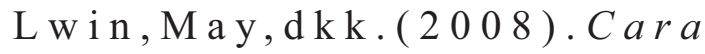
Mengembangkan Berbagai $\begin{array}{llllllll}K & o & m & p & o & n & e & n\end{array}$ Kecerdasan. Yogyakarta: Indeks. Pembayun,Ellys Lestari.(2012). Communication Quotient : kecerdasan komunikasi dalam pendekatan emosionall dan spiritual. Bandung : Remaja Rosdakarya

S.Rahman \& Gustav Asyrint. (2009). The true power smile. Yogyakarta : Aura

Sutarno NS. (2006). Manajemen Perpustakaan. Jakarta : Sagung Seto

Somad, Rismi \& Priansa, Donni J. (2014). Manajemen Komunikasi : Mengembangkan Bisnis Berorientasi Pelanggan. Alfabeta. Bandung. 